HUNGARIAN AGRICULTURAL ENGINEERING

$N^{\circ} 37 / 2020$ 60-66

Published online: http://hae-journals.org/

HU ISSN 0864-7410 (Print) / HU ISSN 2415-9751(Online)

DOI: 10.17676/HAE.2020.37.60

Received: 25.11.2019. - Accepted: 01.03.2020
PERIODICAL OF THE COMITTEE OF AGRICULTURAL AND BIOSYSTEM

ENGINEERING OF

THE HUNGARIAN ACADEMY OF SCIENCES

and

SZENT ISTVÁN UNIVERSITY

Faculty of Mechanical Engineering

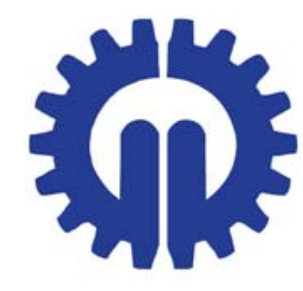

\title{
DEVELOPMENT OF A HIGH PROTEIN CONTAINING FILLING FOR BAKERY PRODUCTS
}

\author{
Author(s): \\ A. Tóth ${ }^{1}$, Cs. Németh 1 , K. Hidas², P. Póti , F. Pajor², A. Barkó², E. Hamar ${ }^{2}$ and L. Friedrich²

\section{Affiliation:} \\ ${ }^{1}$ Capriovus Ltd. Dunasor 073/72 hrsz. Szigetcsép, H-2317, Hungary \\ ${ }^{2}$ Department of Refrigeration and Livestock Products Technologies, Szent István University \\ Ménesi út 43-45., Budapest, $\mathrm{H}-1118$, Hungary \\ Email address: \\ nemeth.csaba@capripvus.hu, toth.drnn@gmail.com
}

\begin{abstract}
Development of nutrient-dense foods is one of the most important goals of today's food industry. High protein content of foods helps to provide energy and amino acids for human body.

In our study protein enriched filling was developed for donates. The main ingredients of the product were pudding powder and egg white product (TOTu, ToTu tej, ToTu krém, and ToTu krém extra).

The texture of samples was analyzed by Anton Paar Mcr 92 rheometer and the quality of products was evaluated by sensorial tests. Microbiological decontamination of HHP was investigated ( $500 \mathrm{MPa}, 5 \mathrm{~min}$ ).

Our results show that high protein content did not influence the sensorial quality of filling, as long the microbiota of the products is highly improved by HHP treatment. Rheological properties are highly influenced by the concentration of egg proteins.

The overall quality will be better, if egg white products are used for the product.
\end{abstract}

Keywords: bakery fillings, egg white, ToTu, protein enrichment

\section{Introduction}

Egg white is a key ingredient in many food products as it combines high nutritional quality (Seuss-Baum, Nau, and Guérin-Dubiard 2011) with excellent functional properties (de Souza and Fernández 2013). However, egg white is also one of the leading causes of IgE mediated food allergy in childhood (Moneret-Vautrin 2008; Lechevalier, Guérin-Dubiard, Anton, Beaumal, David Briand, Gillard, Le Gouar, Musikaphun, Pasco, et al. 2017). Hen egg may also one of the leading causes of food allergy in childhood, affecting $1.6-3.2 \%$ of young children (Eggesbø et al. 2001). Studies are investigating the role of different allergic reactions in childhood in concection whith egg consumption (Robinson and Lanser 2018).

The high content of essential amino acids in egg white proteins and the high bioavailability of these proteins are of great benefit to human nutrition (Hester 2017; Lechevalier, Guérin-Dubiard, Anton, Beaumal, David Briand, Gillard, Le Gouar, Musikaphun, Pasco, et al. 2017). However, the effects of industrial processing such as dry heating on the nutritional quality of egg white proteins have been poorly documented. Some studies considered the effect of dry heating on the in vitro digestibility of proteins as it is a prerequisite to nutritional quality (Schmidt et al. 2007), but the effects of minimal processing technologies are not investigated in case of egg white. Studies are viable about the digestibility assays confirmed previous findings that exposure of egg white to high temperatures increased digestibility markedly. However, it seems that the effects of $\mathrm{pH}$ and salt concentrations were found to be minimal (Lassé et al. 2015).

In the egg product industry, microbiological safety of liquid products is mainly guaranteed by pasteurisation. The USDA requires that liquid whole egg is at least heated at $60^{\circ} \mathrm{C}$ for no less than $3.5 \mathrm{~min}$, but in the United Kingdom the recommendations are to pasteurize at least at $64^{\circ} \mathrm{C}$ for $2.5 \mathrm{~min}$ (Rossi et al. 2010; Korver and McMullen 2017). In France, there is no statutory heat treatment; only microbiological results are determined by regulations. To achieve this, the treatments classically used to pasteurize whole egg vary from 65 to $68^{\circ} \mathrm{C}$ for $2-5 \mathrm{~min}$ in order to ensure 5 to 6 decimal reductions of vegetative microorganisms and especially 
Salmonella Enteritidis and Listeria monocytogenes (F. Baron, Jan, and Jeantet 2010). Pasteurisation temperatures used in the egg industry are limited by the sensitivity of egg proteins to heat treatment. Thus, pasteurisation for $2-10 \mathrm{~min}$ from 60 to $68^{\circ} \mathrm{C}$ modifies whole egg electrophoretic pattern by especially decreasing ovotransferrin, livetin, ovalbumin, apovitellenin, lysozyme and/or ovomucin band intensity (Bartlett and Hawke 1995; Rossi et al. 2010; Lechevalier, Guérin-Dubiard, Anton, Beaumal, David Briand, Gillard, Le Gouar, Musikaphun, Tanguy, et al. 2017).

Liquid egg white (LEW) and egg white-based products are usually regarded as functional foods for their excellent source of high-quality proteins, trace minerals, and for the ability of their components to coagulate, and to form foams when whipped. HHP is one of the most promising minimal processing technologies in the food industry, but only a few scientific studies are existing about HHP treatment and its effects on egg products (Toth et al. 2017).

On the other hand, egg white products are free from gluten, lactose and containing almost zero carbohydrates, these characteristics led to an increasing market of consumers, like people living on a paleolite, or low carb diet, or living with an allergic disease, or sensitivity against lactose, milk protein or gluten.

The goal of our experiment is to develop a special vanilla taste filling from egg white products, which has an increased protein content.

\section{Materials and methods}

\section{The Sample preparing}

\section{Material used for the development}

\section{Cortina}

Cortina is a special puddings in powdered form which is used in pastry industry and has excellent sensorial quality. The major advantages of Cortina are the fast and cold solubility and an excellent viscosity during filling procedure. Concentration of Cortina is usually $0,300-0,470 \mathrm{~kg} / \mathrm{L}$ water, depending on desired texture.

Nutritional labelling is summarized in Table 1. containing the different concentrations of Cortina saluted in water.

Table 1. Nutritional labelling of Cortina, with the different concentrations of Cortina soluted in water

\begin{tabular}{|c|c|c|c|c|c|}
\hline Nutrients & dimension & in dry Cortina & $\begin{array}{c}0,300 \mathrm{~kg} / 1 \mathrm{~L} \\
\text { water dissolved }\end{array}$ & $\begin{array}{c}0,400 \mathrm{~kg} / 1 \mathrm{~L} \\
\text { water dissolved }\end{array}$ & $\begin{array}{c}0,470 \mathrm{~kg} / 1 \mathrm{~L} \\
\text { water dissolved }\end{array}$ \\
\hline energy & $\mathrm{KJ} / 100 \mathrm{~g}$ & 1662 & 383,5 & 474,9 & 531,4 \\
\hline & $\mathrm{Kcal} / 100 \mathrm{~g}$ & 392,2 & 90,5 & 112,1 & 125,4 \\
\hline fat & $\mathrm{g} / 100 \mathrm{~g}$ & 4 & 0,9 & 1,1 & 1,3 \\
\hline $\begin{array}{c}\text { unsaturated } \\
\text { fatty acids }\end{array}$ & $\mathrm{g} / 100 \mathrm{~g}$ & 3 & 0,7 & 0,9 & 1,0 \\
\hline carbohydrates & $\mathrm{g} / 100 \mathrm{~g}$ & 85 & 19,6 & 24,3 & 27,2 \\
\hline sugar & $\mathrm{g} / 100 \mathrm{~g}$ & 60 & 13,8 & 17,1 & 19,2 \\
\hline dietary fiber & $\mathrm{g} / 100 \mathrm{~g}$ & $<0,1$ & $<0,1$ & $<0,1$ & $<0,1$ \\
\hline protein & $\mathrm{g} / 100 \mathrm{~g}$ & 4 & 0,9 & 1,1 & 1,3 \\
\hline Salt & $\mathrm{g} / 100 \mathrm{~g}$ & 1,4 & 0,3 & 0,4 & 0,4 \\
\hline Water & $\mathrm{g} / 100 \mathrm{~g}$ & 4 & 0,9 & 1,1 & 1,3 \\
\hline $\begin{array}{c}\text { trans-fatty } \\
\text { acids: }\end{array}$ & $\mathrm{g} / 100 \mathrm{~g}$ & $<0,1$ & $<0,1$ & $<0,1$ & $<0,1$ \\
\hline bred unit: & $\mathrm{BE} / 100 \mathrm{~g}$ & 7,1 & 1,6 & 2 & 2,3 \\
\hline
\end{tabular}




\section{ToTu products}

ToTu products are made from egg white due to an enzymatic reaction. The different ToTu products have different textures and taste. The original goal of the ToTu products was to offer a lactose- and milk proteinfree dairy analogue for people living with allergic reactions against milk ingredients.

\section{ToTu}

ToTu is a cottage-cheese analoge. The texture is cloddish, similar ot Hungarian "rögös túró". ToTu is rich in protein, but has lower energy content compared with cottage cheese.

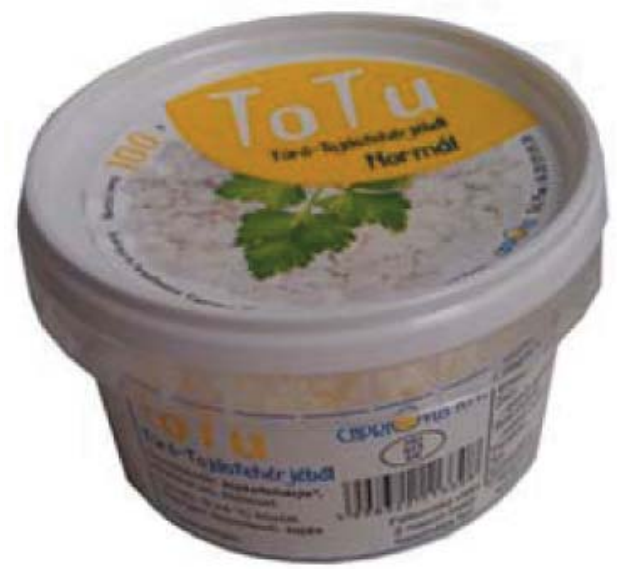

Figure 1. ToTu, the cottage cheese analogue from egg white

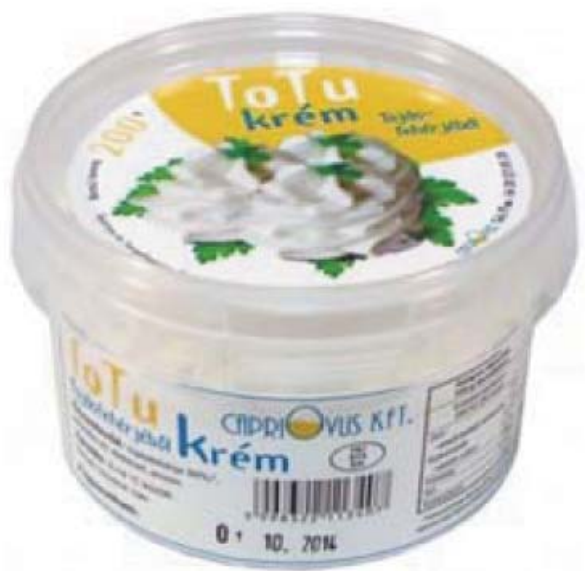

Figure 2. ToTu cream, the sauercream analogue from egg whitecoconut fiber medium , June 09, 2019

\section{ToTu cream}

ToTu cream is has a texture similar to sauercream. The texture is spoonable, viscosity of ToTu cream is higher compared with fermented dairy products (like yogurt, kefir).

\section{ToTu cream extra}

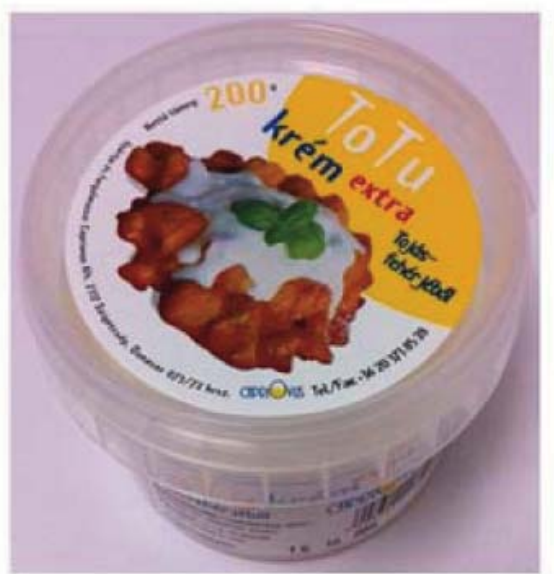

Figure 3. ToTu cream extra, the butter cream analogue from egg white

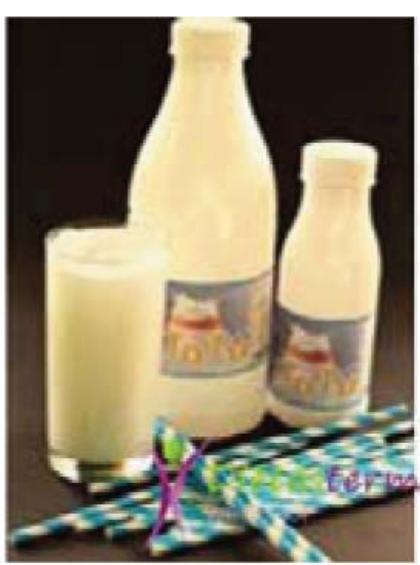

Figure 4. ToTu milk, the cow milk analog from egg white 
ToTu cream extra has a texture like buttercream, or cheese cream. The product is spreadable.

\section{ToTu milk}

ToTu milk is liquid as cow milk. The sensorial attributes are similar to normal milk. Techno functional and sensorial properties like viscosity are similar to normal, or lactose-free milk.

\section{Methods}

\section{Protein enrichment of pastry fillings}

Pilot experiments pointed out, that the most important attributes of foods are sensorial characteristics, like taste and odor for Hungarian consumers. This point of view led us to develop the fillings according to sensorial tests.

First texture and taste were examined with a sensorial panel. Two different fillings were chosen for the next step of examination. The ingredients of the two types of fillings were:

$-150 \mathrm{~mL}$ ToTu milk, $45 \mathrm{~g}$ Cortina and $0,1 \mathrm{~m} / \mathrm{m}$ vanilla flavor

$-100 \mathrm{~mL}$ ToTu milk, $40 \mathrm{~g}$ Cortina, $20 \mathrm{~g}$ ToTu cream and $0,1 \mathrm{~m} / \mathrm{m}$ vanilla flavour

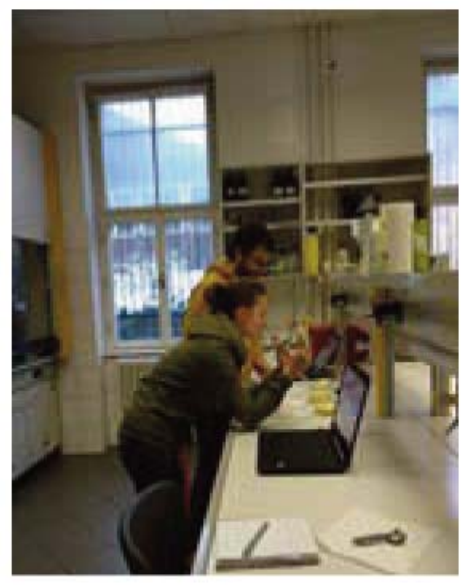

Figure 5. Sensorial testing of developed samples

12 panellists were taking part in t5he experiment they had to evaluate the samples between 1 and 5 . The best evaluation was 5. Examined attributes were: colour, spoonability, door, out flavour, texture, taste (overall), vanilla flavour, sweet taste, out-taste, overall quality. Finally they had to make a ranking of two developed and original samples.

\section{Rheological methods}

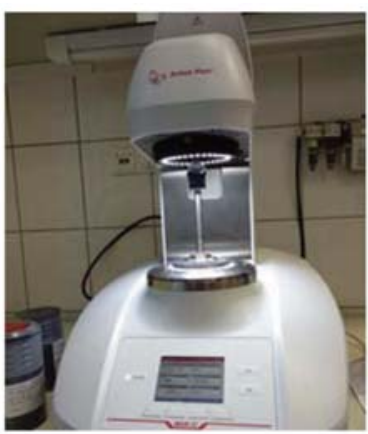

Figure 6. Anton Paar MCR 92 rheometer

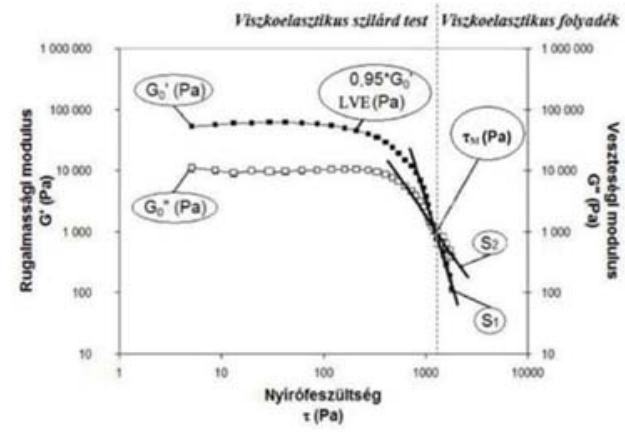

Figure 7. Parameters of amplitude sweeps method 
Rheological properties were measured with an Anton Paar Mcr 92 rheometer. The method was an amplitude sweeping between 0 and $100 \%$. From every samples G' and G" curves were measured and yield point and flow point were calculated. Figure 7. demonstrates the different values measured and calculated by using the method.

\section{Results}

Table 2. Nutritional labelling of ToTu milk, Cortina soluted in watzer, and Cortina soluted in ToTu milk

\begin{tabular}{|c|c|c|c|c|}
\hline Nutrients & Dimension & Totu milk & $\begin{array}{c}\text { Sample with ToTu } \\
\text { milk }\end{array}$ & $0,300 \mathrm{~kg} / 1 \mathrm{~L}$ water \\
\hline energy & $\mathrm{KJ} / 100 \mathrm{~g}$ & 383,5 & 97 & 458,2 \\
\hline Kcal/100 g & 90,5 & 23 & 108,2 \\
\hline fat & $\mathrm{g} / 100 \mathrm{~g}$ & 0,9 & 0 & 0,9 \\
\hline $\begin{array}{c}\text { unsaturated fatty } \\
\text { acids }\end{array}$ & $\mathrm{g} / 100 \mathrm{~g}$ & 0,7 & 0 & 0,7 \\
\hline $\begin{array}{c}\text { carbohydrates } \\
\text { sugar }\end{array}$ & $\mathrm{g} / 100 \mathrm{~g}$ & 19,6 & 0,1 & 19,7 \\
\hline dietary fiber & $\mathrm{g} / 100 \mathrm{~g} / 100 \mathrm{~g}$ & 13,8 & 0,1 & 13,9 \\
\hline protein & $\mathrm{g} / 100 \mathrm{~g}$ & $<0,1$ & $<0,1$ & $<0,1$ \\
\hline Salt & $\mathrm{g} / 100 \mathrm{~g}$ & 0,9 & 5,6 & 5,2 \\
\hline Water & $\mathrm{g} / 100 \mathrm{~g}$ & 0,3 & 0,1 & 0,3 \\
\hline $\begin{array}{c}\text { trans-fatty acids: } \\
\text { bred unit: }\end{array}$ & $\mathrm{g} / 100 \mathrm{~g}$ & 0,9 & & $<0,1$ \\
\hline & $\mathrm{BE} / 100 \mathrm{~g}$ & 1,6 & & 2,1 \\
\hline
\end{tabular}

Table 2 summarizes the nutritional labelling of developed fillings comparing with ToTu milk and with Cortina. The table highlights that protein content of pastry fillings were higly increased by adding ToTu products.

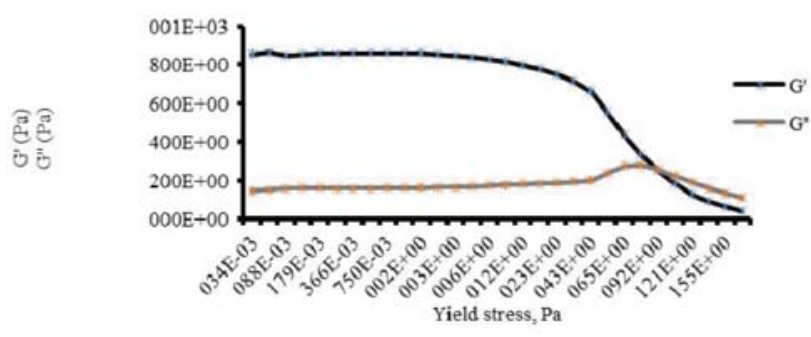

Figure 9. Rheogram of Cortina $(300 \mathrm{~g} / \mathrm{L})$

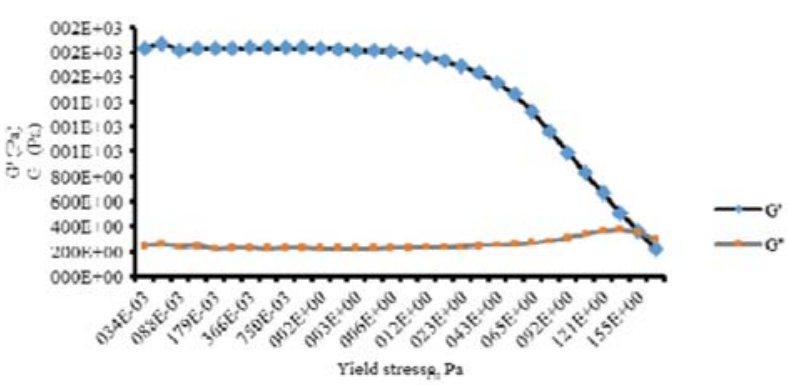

Figure 10. Rheogram of developed filling made with ToTu cream and ToTu milk

Figure 9. shows the rheogram of filling made with Cortina, compairing with Figure 10 and 11 has to be considered, that G' increased by adding ToTu cream and milk, mut the highest impact has ToTu milk on G'. In contrast, G" shlightly decreased by adding ToTu products. 


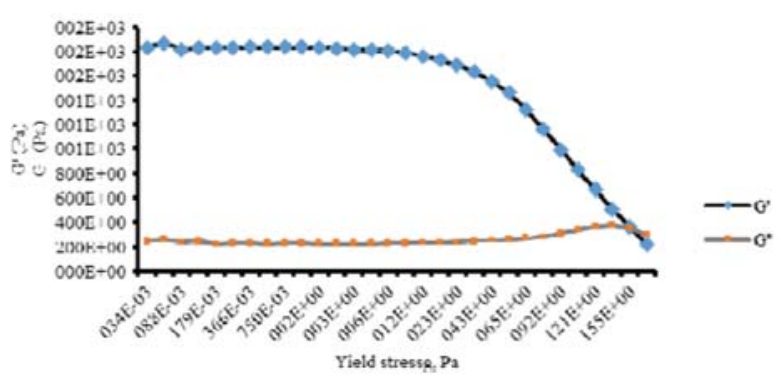

Figure 11. Rheogram of developed filling made with ToTu milk

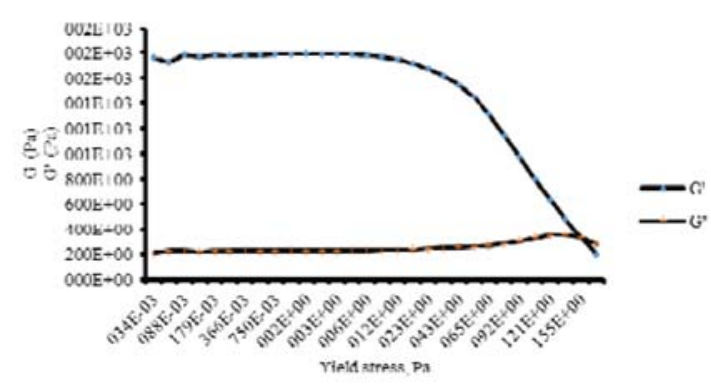

Figure 12. Results of sensorial tests

Rheological properties of developed fillings are summarized in Figure 12. The best sensorial evaluation was fitted to the developed filling with ToTu milk, as long as this sample was the first in ranking of the three different evaluated samples.

\section{Conclusions}

The protein-dense foods are getting tzoday a more and more important role in special diets. In our experiment a protein enriched filling for vdifferent bakery and condictionary products, especially donuts was developed. According to our results, the techno-functional properties of the new products are similar, like the original, as long sensorila attributes are liked and nutritional aspects of developed filling are better.

\section{Acknowledgements}

Our research is supported by EFOP-3.6.3.- VEKOP-16-2017-00005 and by „Egg white based dairy product analogs with probiotic effects for allergic people and development of low-fat and carbohydrate products for people on a protein-dense diet VÁLLALATI KFI_16"". We are very thankful for that. We are very grateful for the help of the colleges of Capriovus Ltd and Dep. of Refrigeration and Livestock Products Technologies.

\section{References}

[1] Baron, F., S. Jan, and R. Jeantet. 2010. "Qualité Microbiologique Des Ovoproduits.” Sciences et Technologie de l'œuf: De l'œuf Aux Ovoproduits, 321-49.

[2] Baron, Florence, Françoise Nau, Catherine Guérin-Dubiard, Sylvie Bonnassie, Michel Gautier, Simon C. Andrews, and Sophie Jan. 2016. "Egg White versus Salmonella Enteritidis! A Harsh Medium Meets a Resilient Pathogen.” Food Microbiology 53: 82-93. https://doi.org/10.1016/j.fm.2015.09.009.

[3] Bartlett, F. M., and A. E. Hawke. 1995. "Heat Resistance of Listeria Monocytogenes Scott A and HAL 957E1 in Various Liquid Egg Products." Journal of Food Protection 58 (11): 1211-14. https://doi.org/10.4315/0362-028X-58.11.1211.

[4] Eggesbø, M., G. Botten, R. Halvorsen, and P. Magnus. 2001. "The Prevalence of Allergy to Egg: A Population-Based Study in Young Children." Allergy 56 (5): 403-11. https://doi.org/10.1034/j.13989995.2001.056005403.x.

[5] Elgaddafi, Rida, Ramadan Ahmed, and Fred Growcock. 2016. "Settling Behavior of Particles in FiberContaining Herschel Bulkley Fluid.” Powder Technology 301: 782-93. https://doi.org/10.1016/j.powtec.2016.07.006.

[6] Fort, N., T. C. Lanier, P. M. Amato, C. Carretero, and E. Saguer. 2008. "Simultaneous Application of Microbial Transglutaminase and High Hydrostatic Pressure to Improve Heat Induced Gelation of Pork Plasma." Meat Science 80 (3): 939-43. https://doi.org/10.1016/j.meatsci.2008.02.009. 
[7] Hester, Patricia Y. 2017. "Chapter 6 - Breeder Hen Influence on Nutrient Availability for the Embryo and Hatchling." In Egg Innovations and Strategies for Improvements, 55-63. San Diego: Academic Press. https://doi.org/10.1016/B978-0-12-800879-9.00006-8.

[8] Korver, Doug, and Lynn McMullen. 2017. "Chapter 4 - Egg Production Systems and Salmonella in Canada." In Producing Safe Eggs, 59-69. San Diego: Academic Press. https://doi.org/10.1016/B978-0-12802582-6.00004-5.

[9] Lassé, Moritz, Santanu Deb-Choudhury, Stephen Haines, Nigel Larsen, Juliet A. Gerrard, and Jolon M. Dyer. 2015. "The Impact of PH, Salt Concentration and Heat on Digestibility and Amino Acid Modification in Egg White Protein." Journal of Food Composition and Analysis 38 (March): 42-48. https://doi.org/10.1016/j.jfca.2014.08.007.

[10] Lechevalier, Valerie, Catherine Guérin-Dubiard, Marc Anton, Valérie Beaumal, Elisabeth David Briand, Angelique Gillard, Yann Le Gouar, Nuttinee Musikaphun, Gaëlle Tanguy, et al. 2017. "Pasteurisation of Liquid Whole Egg: Optimal Heat Treatments in Relation to Its Functional, Nutritional and Allergenic Properties." Journal of Food Engineering 195: 137-49.

https://doi.org/10.1016/j.jfoodeng.2016.10.007.

[11] Lechevalier, Valerie, Catherine Guérin-Dubiard, Marc Anton, Valérie Beaumal, Elisabeth David Briand, Angelique Gillard, Yann Le Gouar, Nuttinee Musikaphun, Maryvonne Pasco, et al. 2017. "Effect of Dry Heat Treatment of Egg White Powder on Its Functional, Nutritional and Allergenic Properties." Journal of Food Engineering 195 (Supplement C): 40-51. https://doi.org/10.1016/j.jfoodeng.2016.09.022.

[12] Moneret-Vautrin, D.-A. 2008. "Epidemiology of Food Allergy." Revue Francaise d'Allergologie et d'Immunologie Clinique 48 (3): 171-78. https://doi.org/10.1016/j.allerg.2008.01.018.

[13] null null. 2014. "Scientific Opinion on the Public Health Risks of Table Eggs Due to Deterioration and Development of Pathogens." EFSA Journal 12 (7): 3782. https://doi.org/10.2903/j.efsa.2014.3782.

[14] Robinson, Melissa L., and Bruce J. Lanser. 2018. "The Role of Baked Egg and Milk in the Diets of Allergic Children." Immunology and Allergy Clinics of North America, Food Allergy, 38 (1): 65-76. https://doi.org/10.1016/j.iac.2017.09.007.

[15] Rossi, Margherita, Ernestina Casiraghi, Laura Primavesi, Carlo Pompei, and Alyssa Hidalgo. 2010. "Functional Properties of Pasteurised Liquid Whole Egg Products as Affected by the Hygienic Quality of the Raw Eggs." LWT - Food Science and Technology 43 (3): 436-41.

https://doi.org/10.1016/j.lwt.2009.09.008.

[16] Sanz-Puig, Maria, Patricia Moreno, M. Consuelo Pina-Pérez, Dolores Rodrigo, and Antonio Martínez. 2017. "Combined Effect of High Hydrostatic Pressure (HHP) and Antimicrobial from AgroIndustrial by-Products against S. Typhimurium.” LWT - Food Science and Technology 77: 126-33. https://doi.org/10.1016/j.lwt.2016.11.031.

[17] Schmidt, L.D., G. Blank, D. Boros, and B.A. Slominski. 2007. "The Nutritive Value of Egg By-Products and Their Potential Bactericidal Activity: In Vitro and in Vivo Studies." Journal of the Science of Food and Agriculture 87 (3): 378-87. https://doi.org/10.1002/jsfa.2685.

[18] Seuss-Baum, I., F. Nau, and C. Guérin-Dubiard. 2011. “The Nutritional Quality of Eggs.” In Improving the Safety and Quality of Eggs and Egg Products, 2:201-36. https://doi.org/10.1533/9780857093929.3.201.

[19] Sheng, Long, Yibo Wang, Jiahui Chen, Jie Zou, Qi Wang, and Meihu Ma. 2018. "Influence of HighIntensity Ultrasound on Foaming and Structural Properties of Egg White." Food Research International 108 (June): 604-10. https://doi.org/10.1016/j.foodres.2018.04.007.

[20] Souza, Poliana Mendes de, and Avelina Fernández. 2013. "Rheological Properties and Protein Quality of UV-C Processed Liquid Egg Products." Food Hydrocolloids 31 (1): 127-34.

https://doi.org/10.1016/j.foodhyd.2012.05.013.

[21] Toth, Adrienn, Csaba Nemeth, Ferenc Horváth, Ildiko Zeke, and Lászlo Friedrich. 2017. "Impact of HHP on Microbiota and Rheological Properties of Liquid Egg White, a Kinetic Study." Journal of Biotechnology, European Biotechnology Congress 2017 held in Dubrovnik, Croatia during 25 - 27 May 2017, 256 (Supplement): S93. https://doi.org/10.1016/j.jbiotec.2017.06.1119. 